\title{
Estetisasi Jilbab Syar'i Jama'ah Salafi: Studi Kasus di Pondok Pesantren Imam Muslim Kota Kediri
}

\author{
Prima Ayu Rizqi Mahanani, ${ }^{1}$ Irwan Abdullah, ${ }^{2}$ Ratna Noviani ${ }^{3}$ \\ ${ }^{1}$ Fakultas Ushuluddin dan Dakwah IAIN Kediri, mahasiswa Program S3 Kajian Budaya \\ dan Media Pascasarjana Universitas Gadjah Mada, 2, ${ }^{3}$ Kajian Budaya dan Media \\ Pascasarjana Universitas Gadjah Mada, Yogyakarta - Indonesia
}

\begin{abstract}
Industry of fashion that get into the life of Salafi members makes shar'i hijab become aesthetics. Approximately 30\% of Salafi women in Imam Muslim Islamic Boarding School Kediri have worn hijab shar'i as their preference. This article describes the aesthetic practices of shar'i hijab and the factors behind it. This study applies a qualitative approach using a case study as a research method in which it observes the social reality of shar'i hijab aesthetic practices among Salafi women at Imam Muslim Islamic Boarding School. The research analyzes the case and situation that occurred and also attempts to understand the informants' point of view. Through literature studies, participatory observation, and in-depth interviews, the study found that the informants have been wearing two different shar'i hijab; dark colors and bright colors. The informants also combine their "gamis" in terms of its pattern consisting of ornaments and accents in different colors. The informants also prefer to wear a unique and funny, in order to make them look flexible, younger and up to date.

Industri mode yang telah memasuki kehidupan jamaah Salafi membuat jilbab syar'i mengalami estetisasi. Sekitar 30\% perempuan Salafi di lingkungan Pondok Pesantren Imam Muslim Kota Kediri menggunakan jilbab syar'i yang sesuai dengan pilihannya. Artikel ini mendeskripsikan praktik estetisasi jilbab syar'i yang terjadi dan faktor-faktor yang mempengaruhinya. Penelitian ini menggunakan pendekatan kualitatif dengan metode studi kasus yang mengungkapkan realitas sosial yang diamati tentang praktik estetisasi jilbab syar'i di kalangan perempuan Salafi di pondok tersebut. Peneliti melakukan analisis mendetail mengenai kasus dan situasi yang terjadi dengan berusaha memahaminya dari sudut pandang informan. Dari hasil pengumpulan data menggunakan kajian pustaka, pengamatan partisipasipatif, dan wawancara mendalam, fakta menunjukkan informan menggunakan dua model jilbab syar'i yakni jilbab berwarna gelap dan jilbab warnawarna terang. Pada gamisnya terdapat kombinasi kain motif yang hiasan atau aksennya tidak senada warna. Informan juga menyukai bentuk manset tangan dan krah yang unik dan lucu yang berkesan fleksibel, ingin terlihat lebih muda, dan mengikuti perkembangan tren kekinian.
\end{abstract}

Keywords: aestheticization; headscarves; shariah; fashion; Salafi women

Korespondensi Penulis: Prima Ayu Rizqi Mahanani (ayurizqi273@gmail.com). Fakultas Ushuluddin dan Dakwah IAIN Kediri, Jawa Timur, Indonesia 64127. 


\section{Pendahuluan}

Jilbab merupakan nama yang paling umum untuk gaya berpakaian di Indonesia. Ia menjadi piranti yang dianggap penting dalam praktik beragama di kalangan perempuan pemeluk agama Islam di Indonesia. Dari data yang ada, 87\% penduduk Indonesia beragama Islam. Dalam khazanah keislaman, jilbab tidak sekadar pakaian, namun sebuah tanda yang diyakini bermakna ketaatan kepada Tuhan dengan merujuk pada alQur'an dan hadis. Jilbab dipercayai karena memberikan nilai kesalehan, ketaqwaan, kesopanan, dan kehormatan diri bagi pemakainya.

Secara umum, kategori jilbab dibedakan menjadi tiga, yaitu jilbab besar atau jilbab syar'i, jilbab biasa, dan jilbab gaul atau funky. Berkaitan dengan korpus penelitian ini, jilbab syar'i, para ulama Salafi menjelaskan definisi yang dimaksudkan dalam al-Qur'an mencakup penutup wajah, yaitu niqab maupun burqa. Cadar, nikab, burkak, purdah, penutup wajah dan apa pun namanya bukan tergolong pakaian eksklusif kelompok tertentu. Ia tidak termasuk pula pakaian khas wanita Saudi atau diidentikkan dengan golongan Salafi/Wahabi yang dikait-kaitkan terorisme. Ajaran menutup wajah bagi kaum wanita bukanlah hal baru dalam budaya umat Islam dari masa ke masa. Hal ini terkait persoalan ketidakadilan pemberitaan media massa terhadap muslimah bercadar -yang keberadaannya dikecam, disudutkan, dan didiskriminasikan- hanya karena menutup wajahnya (Baswedan 2013:40-41).

Ustadz Abdul Adhim, pemimpin Pondok Pesantren Imam Muslim Kota Kediri, menjelaskan istilah jilbab syar'i -berasal dari Bahasa Arabsebagai cara berpakaian yang sesuai tuntunan dan syar'iat Allah yang harus ditaati. Hal ini berdasarkan dalil-dalil sebagai landasan hukum, yaitu al-Qur'an, sunnah, qiyas, dan ijma. Menurutnya, jilbab syar'i bukanlah semata-mata budaya bangsa Arab, akan tetapi benar-benar syar'iat Allah yang berlaku bagi seluruh kaum muslimah karena al-Qur'an tercipta untuk seluruh umat manusia di dunia.

Salah seorang ulama besar yang menjadi rujukan kelompok Salafi, al-Albani (2014:114), melengkapi penjelasan ustadz Abdul Adhim bahwa wajah bukanlah aurat yang wajib ditutupi dan pendapat ini dinyatakan oleh mayoritas ulama. Kesimpulan dari kitab beliau bahwa kaum wanita, baik merdeka atau budak, diwajibkan untuk menutupi tubuh mereka dengan jilbab ketika hendak keluar rumah. Mereka hanya diperbolehkan untuk membuka wajah dan kedua telapak tangan seperti yang dilakukan kaum wanita pada masa Nabi (al-Albani 2014:123). Berdasarkan pendapat tersebut, pemakaian cadar di lingkungan Ponpes Imam Muslim Kota Kediri dihukumi sunnah bagi jamaahnya dan wajib bagi ustadzah serta pegawai perempuan.

Pemakaian jilbab syar'i Salafi menjadi nyata dan jelas di Indonesia sejak pertengahan 1980-an (Hasan, 2008:31). Kelompok Salafi bergerak dengan mengorganisir kelompok-kelompok kajian Islam yang disebut daurah dan halaqah. Daurah merupakan pelatihan yang diadakan dalam waktu satu minggu hingga satu bulan. Selama itu para peserta berkumpul dan tinggal di suatu tempat untuk mengikuti semua program yang dirancang (Hasan 2008:33). Halaqah dimengerti sebagai forum untuk mempelajari ilmuilmu keislaman. Situasinya ada ustadz, guru, atau pengajar yang memberikan pelajaran-pelajaran 
dan para peserta duduk secara melingkar untuk mendengarkan serta menyimak semua materi (Hasan 2008:32).

Gerakan dakwah Salafi yang semakin pesat di era reformasi didukung oleh berdirinya yayasanyayasan ber-manhaj (metode) Salaf; pembangunan pondok pesantren; pembuatan usaha penerbitan, situs web, blog pribadi, dan jejaring sosial; pendirian dan pengembangan media siaran (televisi dan radio), serta keaktifan para ulama Salaf yang berceramah di media cetak, elektronik (radio dan televisi), online, dan offline (Chozin 2013). Selain itu, jilbab syar'i makin akrab di sekitar kita karena dukungan industri fesyen muslim di Indonesia semakin menggeliat. Salah satunya dicanangkan Indonesia sebagai kiblat fesyen muslim dunia pada 2020 (Utami 2017).

Jilbab syar'i jamaah Salafi pun tidak luput dari sasaran pelaku industri fesyen muslim. Penelitian yang dilakukan Eva F. Amrullah menunjukkan adanya desainer Indonesia yang menciptakan kerudung dan cadar instan (siap pakai). Gaya pakaian islami yang paling konservatif, seperti abaya dan cadar, memiliki "sentuhan Indonesia". Hal ini terlihat pada abaya warna-warni Indonesia, bordir berwarna-warni, dan manikmanik pada cadar. Singkatnya, desainer Indonesia telah mengimpor gaya dan desain dari luar negeri yang diubah ke dalam gaya lokal (Amrullah 2013). Kondisi ini memperlihatkan adanya usaha untuk adaptasi dan apropriasi oleh desainer busana muslim di Indonesia.

Hasil penelitian Abdul Ghofur melihat perubahan mode jilbab sebagai akibat adanya kemampuan manusia dalam berinovasi kebudayaan. Perubahan mode jilbab dari bentuk seder- hana bergeser ke model yang simpel, praktis, dan lebih mengutamakan aspek keindahan daripada penutup aurat. Hal ini tidak dapat dipungkiri bahwa perubahan mode jilbab yang semakin bervariasi memberikan banyak manfaat, seperti mempercantik penampilan, praktis, sopan sehingga jilbab dapat terintegrasi dan diterima oleh masyarakat dan mendorong untuk mengenakannya (Ghofur 2012).

Dalam lokus penelitian ini, pemakaian jilbab syar'i juga dijumpai di lingkungan Ponpes Imam Muslim Kota Kediri. Hal ini terlihat dari pengamatan peneliti pada beberapa perempuan Salafi (sekitar 30\%) yang terpapar keberadaan fesyen jilbab syar'i. Mereka datang acara pengajian khusus muslimah dan tabligh akbar dengan memakai gamis motif di bagian dada; berjilbab warna terang atau mencolok; ada hiasan bordir, renda, payet dan batu-batuan warna-warni pada gamisnya; hiasan pita berwarna emas di pinggiran kerudungnya; bros terpasang di luar kerudung; dan memilih dalaman kerudung (inner) model rambut poni. Cadar yang dikenakan pun terkesan tidak sederhana, ada unsur gayanya, serta bervariasi model dan jenis bahannya.

Pada titik ini, perempuan Salafi memakai jilbab syar'i, cadar, beserta aksesori pendukungnya cenderung mengarah ke fesyen, sehingga terlihat indah, cantik, anggun, elegan, bagus dalam penampilannya. Hal ini menunjukkan adanya multi tafsir dalam memahami ketentuan berjilbab syar'i kelompok Salafi oleh jamaahnya. Gambar-gambar berikut merupakan contoh visual jilbab syar'i dan cadar kelompok Salafi yang tersedia di pasar daring maupun luring.

Dalam konteks ini, keadaan yang ambivalens diperlihatkan oleh perempuan Salafi di lingkung- 


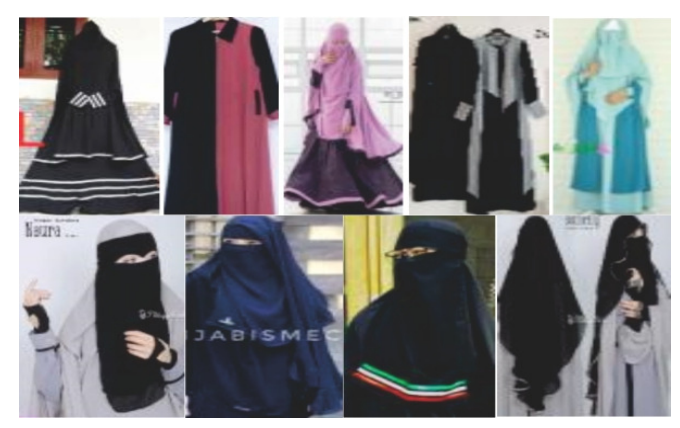

Gambar 1: Contoh Visual Fesyen Jilbab Syar'i Kelompok Salafi

an Ponpes Imam Muslim Kota Kediri. Adanya ketentuan standar mengatur dirinya dalam berjilbab syar'i, akan tetapi ada upaya untuk "menabraknya". Peneliti mempunyai argumen bahwa adanya situasi ingin menjadi muslimah yang taat dan sholihah, tetapi di sisi lain ingin juga "mencicipi" hadirnya varian model jilbab syar'i. Kasus ini memberi arti bahwa ketetapan berjilbab syar'i yang penuh kepentingan ideologis bukan berarti kalau diterima begitu saja oleh perempuan Salafi tanpa adanya "perlawanan".

Perkembangan jilbab syar'i dengan beragam model, varian motif, dan pilihan warna dimungkinkan sebagai pemicu perilaku tersebut. Temuan ini diperkuat oleh pengamatan Siti Maryamah bahwa potensi bisnis jilbab syar'i yang mulai terlacak oleh industri fesyen menjadikan yang sebelumnya simpel menjadi berimpel-rimpel; yang awalnya tebal menutup bisa menjadi tipis menerawang; dan yang tadinya longgar menjadi ketat membentuk. Dengan demikian, jilbab yang seharusnya menutupi pesona menjadi menebar pesona (Maryamah 2016).

Salah satu pemilik gerai jilbab syar'i di Kota Kediri yang juga jamaah Salafi mengatakan bahwa jilbab syar'i dengan model yang indah dan aksen yang cantik diproduksi untuk mempermanis baju agar tidak monoton. Berdasarkan hasil wawancara dengan $\mathrm{N}$ tersebut, hal ini dilakukan agar konsumen tertarik untuk membelinya. Fesyen jilbab syar'i dibuat dalam rangka mengikuti tren yang ada. Tema-tema jilbab syar'i yang fesyen biasanya diproduksi oleh merekmerek besar -seperti Jawhara Syar'i, Lyra Virna Syar'i, Ranee Brugman, Deanara Syar'i, Megawarni Syar'i, dan Kameela Hijabku- yang selanjutnya dicontoh oleh merek lainnya yang belum begitu familiar di telinga konsumen. Dengan kata lain, mereka membuat tiruannya (looklike) dari merekmerek besar tersebut.

Para produsen jilbab syar'i terus membuat inovasi baru, seperti kerudung yang praktis dipakai; gamis indah dengan berbagai aksesori; dan materi kain yang memanjakan pemakainya karena memprioritaskan kenyamanan dan kepercayaan diri konsumennya. Hal ini tentu saja bertolak belakang dengan pemahaman Salafi perihal menutup aurat yang justru melarang perempuan untuk berdandan, berhias berlebihan, dan memamerkan diri. Pada titik ini, hal yang paradoks ditemukan dalam praktik berjilbab syar'i perempuan Salafi sehingga memunculkan pertanyaan penelitian tentang bagaimana perempuan Salafi di lingkungan Ponpes Imam Muslim Kota Kediri melakukan estetisasi pada jilbab syar'i dan alasan yang melatarbelakanginya. Oleh karena itu, penelitian ini dilakukan untuk mendapatkan gambaran komprehensif tentang praktik estetisasi jilbab syar'i oleh perempuan Salafi dan mengetahui faktor-faktor penyebabnya.

Penelitian ini tergolong pendekatan kualitatif dengan metode studi kasus karena mengungkap realitas sosial yang diamati tentang praktik 
estetisasi jilbab syar'i oleh perempuan Salafi di Ponpes Imam Muslim Kota Kediri. Oleh karena itu, peneliti melakukan analisis yang mendetail tentang kasus dan situasi yang terjadi dengan berusaha memahami dari sudut pandang informan (Daymon \& Holloway 2008:162). Prosedur pengumpulan data menggunakan kajian pustaka, pengamatan berpartisipasi (participant observation), wawancara mendalam, dan mendengarkan (Putra 2009:24). Informan penelitian ini adalah pemimpin Ponpes Imam Muslim Kota Kediri (pasangan suami istri), pemilik gerai jilbab syar'i yang juga jamaah Salafi, dan pelaku estetisasi jilbab syar'i.

Alasan peneliti mengambil kasus di Ponpes Imam Muslim Kota Kediri dengan pertimbangan bahwa jamaah yang menuntut ilmu agama di sana mengalami peningkatan yang signifikan sampai awal tahun 2019. Dari pertama berdiri tahun 2006, hanya diikuti oleh puluhan orang saja (sekitar 30-an) dan sekarang mencapai ribuan orang (sudah 1.500-an). Apalagi, pondok pesantren ini merupakan satu-satunya yang bermanhaj Salaf di Kota Kediri. Keberadaannya makin hari juga semakin eksis di tengah kungkungan mayoritas pondok pesantren tradisional yang ada di Kota Kediri, seperti Pondok Pesantren NU Lirboyo, LDII Wali Barokah, dan Wahidiyah.

\section{Nilai Estetika Jilbab Syar'i dalam Pandangan Ulama Salafi}

Pakaian yang kita kenakan mempunyai fungsi etika dan estetika. Berdasarkan hasil wawancara dengan ustadz Abdul Adhim, beliau menjelaskan bahwa pada diri perempuan terdapat dua sumber estetika, yaitu tubuh dan busana beserta pernik perhiasannya. Estetika membuat sese- orang untuk tampil lebih menarik dan indah dipandang. Keindahan atau nilai estetika tubuh perempuan merupakan keindaan yang semestinya dipelihara dan dijaga dari pandangan mata orang lain sesuai dengan etikanya. Demikian halnya, estetika pada busana yang dipakai harus diperhatikan dan dimaksudkan untuk siapa.

Allah menyebut nilai estetika pada diri perempuan dengan aurat, yaitu sesuatu yang terlihat memalukan bagi pemiliknya. Di dalam al-Qur'an, hal ini dikatakan zinah (perhiasan), yaitu terdiri dari: estetika pada asal penciptaan tubuh perempuan, pakaian, dan pernik-pernik aksesori. Dia melarang nilai estetika seluruhnya untuk dilihat oleh kaum yang dilarang dan membolehkan bagi orang-orang tertentu saja.

Pembahasan estetika yang merujuk QS. anNur ayat 31 memberikan keterangan bahwa seluruh tubuh dan perhiasan wanita merupakan aurat yang tidak boleh terlihat orang lain yang bukan mahram, kecuali pakaian luar yang menutup ujung rambut hingga ujung kaki. Ustadz Abdul Adhim memperjelas perhiasan yang boleh dilihat oleh orang-orang yang dikecualikan, yaitu pakaian yang dikenakan, anggota tubuh, dan perhiasan yang ditutupi pakaian luarnya (kepala dan leher, sebagian tangan dan kaki). Pada tempat-tempat tersebut, perempuan biasa menyematkan perhiasan, seperti anting-anting di telinga, kalung di leher, gelang di tangan dan kaki. Oleh karena itu, estetika yang terdapat pada diri wanita adalah keindahan bagian tubuh yang ditutup dengan pakaian dari dada ke bawah, betis ke atas, dan lengan atas ke atasnya.

Hal ini mengharuskan busana luar yang dikenakan untuk bisa menutupi semua nilai 
keindahan pada perhiasan, pakaian, dan terlebih pada tubuhnya. Apabila jilbab syar'i berupa busana yang indah karena mode, potongan, aksesori/perhiasan yang disematkan, ia harus mengenakannya di balik busana luar yang menutupi semua keindahan tersebut karena ini ditujukan untuk laki-laki mahramnya saja. Pada prinsipnya, estetika yang mengatur jilbab syar'i perempuan Salafi terbatas pada keindahan tubuh, pakaian, serta perhiasan yang harus ditutupi dengan pakaian luar, dalam kondisi terlihat oleh laki-laki selain suami dan para mahramnya.

Ustadz Abdul Adhim mengatakan bahwa pada dasarnya kaum wanita boleh berindah-indah dan perlu memperelok penampilannya. Bahkan, seorang wanita dalam beberapa kondisi wajib untuk berhias dan mempercantik dirinya -ketika sebagai istri- untuk memenuhi kesenangan suami. Pada intinya, etika dalam berdandan dan berhias diatur oleh Islam. Hal ini dilakukan guna memperindah penampilan di hadapan para kerabat yang ada hubungan mahram serta memenuhi keinginan dan kesenangan suami, bagi yang sudah menikah. Dengan demikian, estetika pada seorang wanita sangat erat kaitannya dengan kekuatan silaturahim antar mahram serta ketulusan cinta seorang istri kepada suami.

Di sisi lain, wanita yang menampilkan estetika busananya tergolong pendosa. Oleh karena itu, Allah melarang perempuan untuk ber-tabarruj, yaitu ia menampakkan sebagian perhiasan dan keelokan yang wajib untuk ditutupi. Hal ini ditakutkan kalau membangkitkan birahi kaum lakilaki. Menurut ustadz Abdul Adhim, saat ini (tahun 2018) kita mendapati kebanyakan kaum wanita yang ber-tabarruj dengan menampakkan keelokan diri dan keindahan busananya. Mereka mengikuti mode sehingga tidak peduli lagi dengan penampilan dan anggota tubuhnya yang terbuka. Berkaitan dengan itu, wanita sangat membutuhkan penerangan ilmu sekitar hukumhukum pakaian dan busana muslimah.

\section{Praktik Estetisasi oleh Perempuan Salafi: Upaya Menerobos Pagar Syar'i}

Identifikasi jilbab kelompok Salafi yang mudah dikenali adalah kerudung lebar dan panjang seperti mukena, gamis longgar, kain polos, warna cenderung gelap, serta memakai cadar. Ciri-ciri jilbab yang mereka yakini tersebut dikatakan jilbab syar'i karena dianggap paling sesuai dengan perintah Allah di dalam al-Qur'an dan Hadis. Selain itu, mereka juga merujuk cara berjilbab di zaman Rasulullah. Ilustrasi jilbab syar'i kelompok Salafi dapat dicermati pada gambar 2 .

Gambar 2 memperlihatkan pakem jilbab syar'i yang seharusnya dipakai oleh perempuan Salafi. Panduan ini diintisarikan dari buku Wanita dan Mode karangan Ustadz Abu Abdillah Syahrul Fatwa bin Lukman. Beliau mengatakan bahwa pakaian Salafi adalah kain tebal dan polos, bentuk gamis siluet $\mathrm{H}$ yang longgar menutup seluruh badan, tidak bermodel-model, tidak berlebihan dengan hiasan (sesuai fungsinya), dan berwarna gelap (hitam). Kerudung panjang semata kaki, cadar, kaos kaki, dan kaos tangan juga terbebas dari model-model, aksen, dan hiasan apapun (Lukman 2015). Hal ini mengarahkan perempuan Salafi untuk melakukan hal-hal yang diperbolehkan dan tidak. Dalam konteks ini, peneliti berasumsi bahwa buku tersebut diciptakan sebagai bentuk ketegasan agar perempuan 


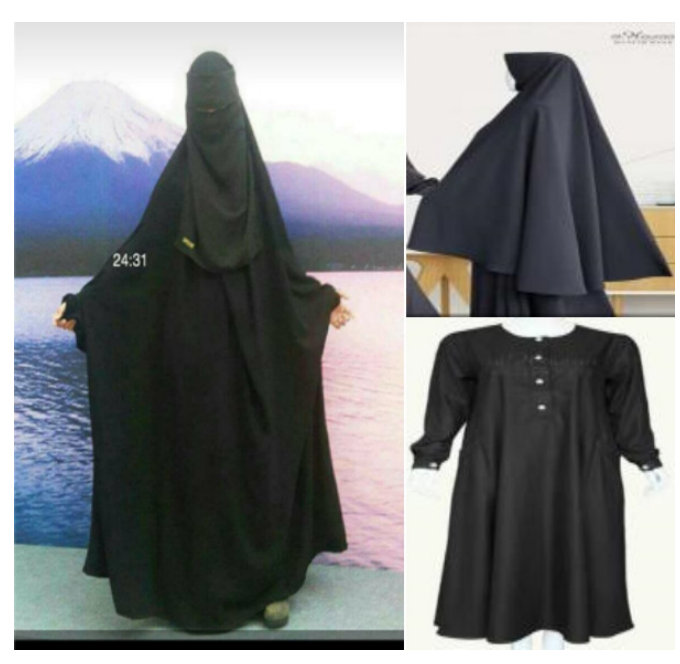

Gambar 2: Contoh Visual Jilbab Syar'i Kelompok Salafi

Salafi tetap berada dalam koridor tata nilai berjilbab syar'i yang disepakati oleh ulama Salafi.

Ulama Salafi telah membuat delapan syarat jilbab syar'i yang bertujuan untuk mengatur perempuan Salafi ketika keluar dari rumahnya, antara lain: 1) menutupi seluruh badan selain bagian yang dikecualikan; 2) tidak dijadikan/ berbentuk perhiasan (misalnya: tabarruj); 3) jilbab harus tebal, tidak tipis; 4) jilbab harus longgar, tidak ketat; 5) tidak dibubuhi parfum atau minyak wangi; 6) tidak menyerupai pakaian lakilaki; 7) tidak menyerupai pakaian wanita-wanita kafir; 8) tidak berupa pakaian syuhrah (mencolok) (al-Albani 2014:49). Pendapat al-Albani banyak dijadikan rujukan oleh kelompok Salafi. Salah satunya adalah kaum wanita -merdeka atau budak- wajib untuk menutupi tubuhnya dengan jilbab ketika hendak keluar rumah.

Ketentuan minimum jilbab syar'i kelompok Salafi berdasarkan hasil wawancara dengan Ummu Ammar, istri pemimpin Ponpes Imam
Muslim Kediri, bahwa jilbab dan cadar tidak boleh kalau terlalu modis dan menarik perhatian. Beberapa contohnya adalah gamis yang ada hiasan cantiknya, cadar yang ada bandulnya, dan cadar bergelombang-gelombang (butterfly). Hal ini berkaitan keutamaan hijab untuk menutup aurat dan berdakwah, bukan bergaya dan terkesan cantik.

$\mathrm{V}$ dan $\mathrm{O}$ sebagai pengguna jilbab yang telah diestetisasi memahami makna jilbab syar'i dengan mengenakan pakaian yang sesuai syar'iat Islam, yaitu berdasarkan al-Qur'an dan Sunnah. Hal ini mendorongnya untuk berjilbab syar'i karena menjadi perintah Allah di QS. al-Ahzab ayat 5. Jilbab dalam tafsir ayat tersebut diakui sebagai pakaian yang menutup seluruh tubuh wanita. Jilbab syar'inya dikatakan bahwa telah merujuk cara berjilbabnya shahabiyat di zaman Rasulullah. Pengetahuan ini diperoleh dari kajian rutin yang diikutinya sejak kuliah. Akan tetapi pada kenyataannya, terpaan industri fesyen jilbab mendorong mereka untuk berjilbab syar'i yang melampaui pakem.

Hal ini terlihat dari pemakaian jilbab syar'i oleh kedua informan yang berbeda tingkat usianya, yaitu $\mathrm{V}$ berusia 33 tahun dan $\mathrm{O}$ berusia 21 tahun pada tahun 2018. Mereka mengedepankan tampilan yang berkesan fleksibel dan ingin terlihat lebih muda dengan menggunakan jilbab syar'i yang telah diestetisasi. Praktik estetisasi yang dilakukannya menitikberatkan pada persoalan warna, penggunaan kain motif, dan pemilihan modelnya. Lila Abu-Lughod dalam Sokowati (2015:11) menyebutkan istilah yang menggambarkan praktik ini sebagai alternative modernity, yaitu memilih menjadi fesyen dengan melakukan kombinasi-kombinasi. 
$\mathrm{V}$ dan 0 melakukan kreasi dengan mengkombinasikan warna yang tidak hanya gelap, seperti: hitam, coklat pekat, ungu tua, merah marun, navy, tapi juga memilih gradasi warna terang, seperti pink, merah fanta, biru laut, biru elektrik. Gamisnya terdapat perpaduan kain motif yang hiasan atau aksennya tidak senada warna. Kategori model terlihat dari bentuk krah, manset tangan, pinggiran bisband, potongan di pinggang, dan model keliling bawah gamisnya yang line A, umbrella, serta setengah umbrella. Jenis krahnya tidak hanya dimodel $V$ atau $U$, akan tetapi sudah beragam bentuknya, seperti kupukupu, daun, dan bunga. Model manset tangan tidak hanya dibuat polosan atau rempel biasa saja, akan tetapi ada model sisik ikan, rantai cinta, pita, dan manset anti manset karena bisa berfungsi sebagai handsock. Gambar 3 menunjukkan koleksi jilbab syar'i informan $\mathrm{V}$ dan $\mathrm{O}$ yang mengalami praktik estetisasi.
Dari gambar tersebut dapat dipahami bahwa ada upaya dari kedua informan untuk menerobos batasan syar'i dengan memakai gamis motif di bagian detail dada dan lengan; tambahan hiasan di pinggiran kerudung dan gamisnya; ada aksen seperti bordir dan rempel; manset tangan dan krah yang dimodel-model unik; serta warna gamis dan kerudung yang dibuat tidak senada. Koleksi jilbab syar'i kedua informan memberikan pemahaman bahwa tarikan-tarikan fesyen menyebabkan jilbab syar'i kelompok Salafi kemudian bergeser dari pakemnya. Masing-masing informan mencoba untuk berbicara agama yang dihadirkan lewat busana yang telah mengalami estetisasi. Berdasarkan penjelasan Abdullah (2006/2015:35), kecenderungan estetisasi dalam kehidupan sehari-hari dapat dilihat dalam tiga proses, yaitu: ada penegasan nilai-nilai khusus, penegasan proses-proses individualisasi dalam dua tingkatan, dan penegasan munculnya "kekuatan baru".

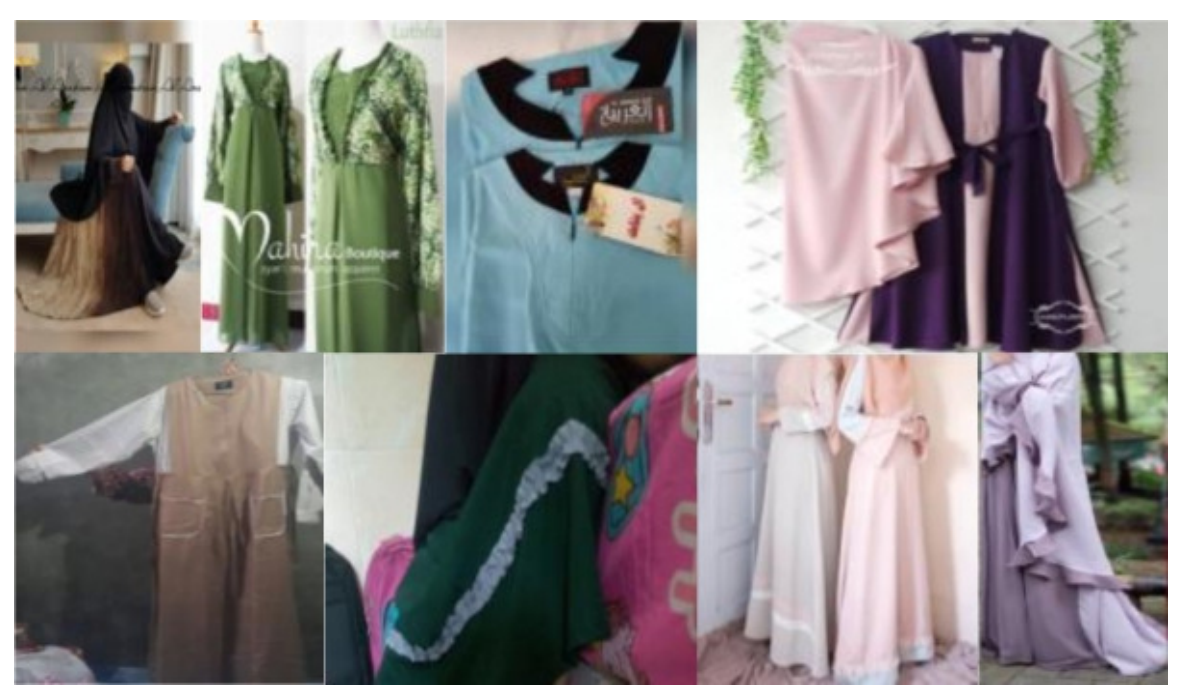

Gambar 3: Koleksi Pribadi Fesyen Jilbab Syar'i Informan V dan Informan O 
Dalam konteks ini, masing-masing informan berusaha untuk memperlihatkan kemahirannya di dalam mempercantik jilbab syar'i. Praktik estetisasi dilakukan oleh $\mathrm{V}$ dan $\mathrm{O}$ dalam dua tingkatan, yaitu usaha menambahkan aksenaksen pada jilbab syar'i yang membedakan dengan pakem kelompok Salafi dan menyematkan nilai tambah pada jilbab syar'i dalam batas-batas yang masih dapat diterima oleh kelompok. Apabila peneliti prosentasekan, antara syar'i dan modis diperoleh nilai $50 \%$ dan $50 \%$. Hal ini menggambarkan nilai-nilai syar'i dan fesyen yang telah diselaraskan.

Apa yang $\mathrm{V}$ dan $\mathrm{O}$ lakukan tersebut dapat dikatakan bahwa adanya apropriasi yang dianggap oleh kelompok Salafi melampaui pakem. Teori adaptation and cultural appropriation dikembangkan oleh Julie Sanders. Normalisasi pakem jilbab syar'i Salafi telah diapropriasi oleh $\mathrm{V}$ dan 0. Apropriasi merupakan seleksi pada pemikiran dominan yang kemudian diadaptasi pada konteks kelokalan (perempuan Salafi di Kediri), di antaranya: penggunaan jilbab syar'i berwarna cerah; ada kombinasi kain motif; serta pemilihan bahan, model, hiasan, dan aksen yang bervariasi. Di sisi lain, mereka juga melakukan apropriasi pada penggunaan jilbab syar'i bermerek dan harganya mahal.

Mereka mengakui kalau semakin nikmat dalam menutup aurat ketika menggunakan jilbab syar'i yang bermerek dan model terbaru. Hal ini dilakukan karena $\mathrm{V}$ dan 0 sangat mempedulikan kenyamanan dari segi material maupun kepercayaan diri dari aspek modelnya. Dengan demikian, adanya persoalan personal terkait kenikmatan (emosional) yang didapatkan dari penggunaan jilbab syar'i bermerek. Pada titik ini, perempuan Salafi mendapatkan pleasure terkait apa yang dibutuhkannya, yaitu pemenuhan hasrat kepuasan batin yang difasilitasi oleh fesyen jilbab syar'i.

$\mathrm{V}$ dan $\mathrm{O}$ mengklaim bahwa pilihan jilbab syar'inya masih dianggap wajar karena hiasan, kombinasi, aksen yang ditambahkan tidak berlebihan dan posisinya terletak di bagian yang tertutup kerudung. Pemilihan warna terang juga mendasarkan pada hadits yang memperbolehkannya, asalkan tidak sampai menarik perhatian orang lain. Apa yang dilakukannya tersebut hanya sekadar tampil cantik, indah, lucu, dan unik dalam rangka menyenangkan suami bagi $\mathrm{V}$ dan dirinya sendiri bagi O. Dengan demikian, penggunaan fesyen jilbab syar'i disebabkan alasan-alasan yang bersifat pribadi, seperti ingin tampil cantik, anggun, elegan, bersih, rapi, percaya diri, dan muda.

Fakta-fakta yang didapatkan mempertegas pendapat Abdullah (2006; 2015:33) tentang konsumsi yang bersifat estetis. Konsumsi estetis berjalan dalam alur simbolik karena lebih mementingkan unsur keindahan dibanding fungsinya untuk menciptakan pembeda (distingsi) dari yang lain. Menurutnya, hal ini merupakan cara seseorang dalam menggunakan barang untuk membangun batas sosial. Perempuan Salafi berupaya untuk membuat batas antara pengguna jilbab syar'i yang taat pakem dan pengguna jilbab syar'i kelompok Salafi yang fesyen. Kasus ini juga digambarkan dalam penelitian Carla Jones (2007:219) tentang fesyen dan keimanan di wilayah urban di Indonesia. Ia menekankan bahwa kerudung memiliki banyak arti dalam politik, sosial, dan personal yang berkaitan dengan komodifikasi pakaian islami. Identitas 
Islam yang mengisyaratkan adanya potensi politik menjadi cair karena keberadaan busana muslimah yang fashionable dan trendi.

Pada kenyataannya sekarang ini (tahun 2018) memang ada banyak ragam dan varian model, warna, dan merek jilbab syar'i yang sudah menyesuaikan tren. Hal ini menunjukkan kalau fesyen jilbab terus berubah dan berkembang pesat. Hal ini sesuai pernyataan Featherstone (2001/2008:161) bahwa estetisasi kehidupan sehari-hari merujuk pada gerak cepat dan citra yang memenuhi jaringan kehidupan sehari-hari dalam masyarakat kontemporer.

Mereka memilih fesyen jilbab syar'i dikarenakan penampilan yang cantik menjadi persoalan serius dalam performa sehari-harinya. Malcolm Barnard, 2011:28) memperkuat fakta tersebut bahwa semua fesyen dan pakaian adalah untuk mendekorasi atau mempercantik tubuh. Bagi V dan 0 , penggunaan jilbab syar'i yang cantik, bersih, dan bermerek setidaknya bisa mengurangi penilaian yang negatif pada perempuan Salafi karena distigmakan jorok, kotor, kumal, tidak pernah ganti baju, dan acak-acakan. Alasan yang melatari kedua informan tersebut memperkuat pendapat Entwistle (2001:52) bahwa seseorang berbicara tentang pakaiannya. $\mathrm{V}$ dan $\mathrm{O}$ ingin mengomunikasikan jilbabnya yang tidak asal syar'i, tapi syar'i yang berkelas, berkualitas, dan nyaman. Konsumsi jilbab syar'i yang diestetisasi dan bermerek diakuinya seperti ada prestis tersendiri. Mereka merasa bangga dan lebih percaya diri kalau memakai jilbab syar'i yang bermerek. Pada konteks ini, ada pergeseran cita rasa Salafi ke fesyen yang disebabkan banyaknya varian jilbab syar'i yang ditawarkan.
Selain itu, mereka mengakui bahwa jilbab syar'i yang diestetisasi dikenakan dengan mempertimbangkan situasi dan kondisi yang melingkupinya. Salah satu contohnya adalah dengan memperhatikan persoalan geografi ruang yang dibagi menjadi dua area, yaitu di dalam lingkungan Salafi dan di luar lingkungan Salafi. Jilbab syar'i kombinasi yang cantik dikenakan dalam acara pernikahan yang diselenggarakan di luar lingkungan Salafi, seperti di tempat kerja suami, rumah ibu mertua, acara keluarga, kerabat dan teman yang non Salafi, serta kegiatan kampus. John Fiske (2000:323) memperjelas kondisi ini dengan mengatakan bahwa bagaimana orang melihat kita maka akan menentukan bagaimana kita harus menempatkan diri di dalam sebuah relasi sosial. Alasan V dan 0 sangat melihat tempat dalam berjilbab syar'i karena mereka ingin menunjukkan citra diri perempuan Salafi yang fleksibel bagi semua kalangan.

Referensi fesyen jilbab syar'i dan inspirasinya diperoleh dari sumber yang beragam. Rujukan kedua informan untuk warna, model, bahan, motif, hiasan, aksen, gaya, dan aksesori diperoleh dari internet -melalui facebook, instagram, whatsapp, on line shop- dan interaksi sosial yang dilakukan. Koleksi V diperoleh dari media sosial (facebook, instagram, whatsapp) dan sahabatnya di Malang sedangkan 0 mendapatkan fesyen jilbab syar'inya dari toko on line, toko konvensional, dan dari perkumpulan jamaah Ponpes Imam Muslim Kota Kediri.

Berdasarkan pemaparan tersebut menunjukkan jika media memiliki peran penting dalam menyebarkan pengetahuan fesyen jilbab syar'i. Hal ini sejalan dengan pernyataan Strinati 
(2016:294) bahwa perkembangan teknologi dan komunikasi memiliki dampak yang signifikan terhadap cepatnya penyebaran informasi, gambar, maupun orang ke seluruh dunia. Media dipahami memiliki kemampuan untuk mengkonstruksi realitas. Publikasi media yang massif dinilai mampu menetapkan standarisasi produksi budaya. Kehadiran media sosial yang bersifat massif, terutama instagram, facebook, dan whatsapp, tanpa disadari $\mathrm{V}$ dan $\mathrm{O}$ kemudian menjadikan mereka fans dari media popular. Dengan demikian, adanya teks-teks di media sosial mempengaruhi perempuan Salafi dalam menentukan pilihan fesyen jilbab syar'inya. Mereka terus mencari rujukan tren fesyen jilbab syar'i dari media sosial yang dimilikinya.

Dari kasus-kasus penelitian yang dikemukakan, hal ini memberikan gambaran bahwa tidak ada demarkasi apa pun yang bersifat tegas karena segala hal saling berkelindan dan terkait satu sama lain. Persoalan demarkasi syar'i dan modis yang coba diterobos oleh perempuan Salafi menghasilkan konstruksi makna jilbab syar'i yang cenderung berkelindan. Informan $\mathrm{V}$ dan 0 mengonstruksi makna baru dengan menerobos sekat syar'i dan modis yang sifatnya kontinum. Kondisi ini diartikan bahwa tidak ada yang betul-betul syar'i atau modis karena semuanya sudah bercampur (blending). Keduanya bisa jadi saling melengkapi dan bukan saling berlawanan yang cenderung bersifat oposisi biner. Makna syar'i dan modis tidak saling ditiadakan, tetapi keduanya secara produktif saling menghasilkan dan menghidupi.

Dengan kata lain, makna jilbab syar'i yang dibangun $\mathrm{V}$ dan $\mathrm{O}$ cenderung mengambang bebas karena beberapa hal di luar pakem kelompok Salafi ditafsirkan dengan versinya sendiri atau tidak sesuai ketentuan sepenuhnya. Mereka memilih untuk berada di posisi tengahtengah karena keterbatasan kemampuan dalam menjangkau syar'i yang ideal. Menurutnya, jalan yang terbaik adalah dengan mengikuti fesyen jilbab syar'i dan tetap memperhatikan aturan kelompok Salafi. Pada titik ini, adanya demarkasi syar'i yang diterobos oleh perempuan Salafi akhirnya memunculkan pergeseran orientasi dalam praktik berjilbab syar'i di lingkungan Ponpes Imam Muslim Kota Kediri.

Selain mendasarkan ketentuan jilbab syar'i kelompok Salafi -yang lebih kepada persoalan menjalankan syar'iat sebagai perintah Allah dan mengikuti tuntunan Rasulullah serta para sahabiyah-, mereka juga mengikuti tren fesyen jilbab syar'i yang terus berkembang dan berubah. Jilbab syar'i yang digunakan tidak asal mengikuti tren fesyen, tapi memilih yang tetap selaras dengan pakem kelompok Salafi. Dengan demikian, penyuka jilbab syar'i kombinasi berusaha untuk tetap berpegang teguh pada nilai-nilai agama yang menjadi batasannya agar tidak "tersesat" terlalu jauh dalam menikmati tren fesyen jilbab syar'i yang ditawarkan oleh industri budaya.

\section{Distingsi Diri: Menjadi Perempuan Kekinian}

Jilbab syar'i yang dikenakan informan $\mathrm{V}$ dan $\mathrm{O}$ diketahui kalau merepresentasikan sosok muslimah yang taat dan salehah sekaligus mengikuti tren fesyen. Mereka memilih jilbab syar'i yang diestetisasi dengan berusaha tidak melanggar 
batas-batas kesyar'iannya. Mereka berdua tidak ingin memprotes jilbab syar'i yang cenderung gaul, tetapi malah ingin mengajak Muslimah lainnya untuk mengikuti tata cara menutup aurat yang sesuai dengan al-Qur'an dan Sunnah.

Dari fakta-fakta yang didapatkan, interpretasi jilbab syar'i oleh kedua tokoh kelompok Salafi dan kedua informan penelitian ini memberikan penjelasan bahwa setiap individu dalam jamaah Salafi saling memproduksi dan bertukar makna tentang jilbab syar'i. Hal ini terefleksi dari pendapat Hall (1997:2) bahwa budaya berkaitan dengan produksi dan pertukaran makna, pemberian dan pengambilan makna, di antara anggota masyarakat atau kelompok. Titik perhatiannya adalah $\mathrm{V}$ dan $\mathrm{O}$ yang menjadi bagian dari jamaah Salafi mengonstruksi makna jilbab syar'i yang berbeda dengan nilai dominan dalam kelompok.

Adanya kultur kelompok Salafi yang memandu mereka ternyata tidak bisa mencegah usaha $\mathrm{V}$ dan $\mathrm{O}$ untuk menciptakan makna jilbab syar'i dengan versinya sendiri. Kasus ini memberikan pemahaman bahwa bukan dikarenakan alasan kurang ilmu dalam memahami ketentuan jilbab syar'i kelompok Salafi, akan tetapi makna yang beragam muncul ketika menafsirkan persyaratan-persyaratan yang didoktrinkan. Tubuh yang dibalut fesyen jilbab syar'i ditampilkan dan didandani dengan menyesuaikan identitas yang ingin dikonstruksinya. Identitas, seperti yang disampaikan oleh Hall (1997), merupakan proses yang terus menjadi dan tidak pernah selesai sehingga tidak mengenal batasan umur. Dalam hal ini, fesyen menjadi jembatan pencapaian identitas diri yang diinginkan.

Informan $\mathrm{V}$ dan $\mathrm{O}$ diketahui bahwa mereka sedang mengonstruksi identitas kekinian. Fesyen jilbab syar'i tidak sekadar menjadi penanda dalam menutup aurat secara "sempurna", akan tetapi menjadi penanda perempuan yang kekinian, mengikuti tren, dan jauh dari kesan kuno. Mereka ingin menepis anggapan banyak orang tentang perempuan berjilbab syar'i dan bercadar yang identik dengan hal-hal konservatif. Oleh karena itu, $\mathrm{V}$ dan $\mathrm{O}$ menyeimbangkan hal yang dianggap sakral dan profan.

Hal ini harus mereka lakukan karena habitus keluarganya yang kurang mendukung. $V$ dituntut untuk menyesuaikan dengan ibu mertuanya yang tidak menyukai gayanya berjilbab sedangkan 0 melakukan penyesuaian karena ibu dan kakak laki-lakinya yang masih berkatar belakang Nahdlatul Ulama (NU). Dengan demikian, kedua informan menyesuaikan jilbab syar'i dalam tradisi kelompok Salafi dengan perkembangan fesyen jilbab agar bisa diterima oleh keluarganya. Dengan demikian, pakaian syar'inya disesuaikan dengan kondisi zaman agar lebih diterima oleh kerabat dan masyarakat yang masih awam dengan kelompok Salafi.

Adanya upaya untuk membuat cocok, pantas, dan sesuai dengan pilihan, selera, serta lingkungan yang melingkupinya mendorong $\mathrm{V}$ dan $\mathrm{O}$ untuk memilih merek jilbab syar'i yang bisa memenuhi keduanya, yaitu kepentingan pribadi dan sosial. Oleh sebab itu, mereka berusaha untuk menampilkan identitas sebagai perempuan Salafi yang kekinian dan tidak ketinggalan zaman. Citra diri dikelola dengan entitas kekinian melalui upaya-upaya kreatif dalam rangka memantaskan diri atau mematut diri di era modern dan juga menjawab persoalan transendensi. Jadi, sisi keagamaan mereka dapatkan dan secara kehidupan sosial tidak tertinggal. 
Hal ini semacam afirmatif action bahwa syar'inya didapatkan dan fesyennya juga kena. Syar'i dan fesyen digunakan bersama sebagai upaya mengikuti desakan tren yang menerpa $\mathrm{V}$ dan 0. Fesyen menjadi jembatan pencapaian menuju jilbab syar'i yang sesuai selera dan keinginannya. Jilbab syar'inya ditampilkan secara kekinian karena selalu mengikuti perkembangan tren yang ada. Pemilihan model, pola, potongan, material, bentuk krah, varian manset tangan, lebar rok cenderung mengikuti zaman sehingga lebih dinamis, berwarna, bervariasi, tidak monoton, dan tidak lagi dominan pakem.

Keberadaan industri fesyen memfasilitasi V dan $\mathrm{O}$ untuk cenderung dimanis. Batas-batas syar'i dan modis sudah tidak kentara lagi karena $\mathrm{V}$ dan $\mathrm{O}$ memilih fesyen jilbab syar'i yang masih mengikuti pakem kelompok Salafi dan ada nuansa kekiniannya. Mereka membuat distingsi jilbab syar'i "kekinian" dengan memilih terbuka dengan perubahan kondisi sosial yang ada. Pada titik ini, perkembangan tren fesyen jilbab syar'i yang ibarat angin segar dapat dikatakan sebagai bentuk resistensi $\mathrm{V}$ dan $\mathrm{O}$ atas kejenuhan pada cara berjilbab kelompok Salafi. Hal ini berdasarkan alasan trajektorinya di kelompok Salafi yang dirasakan sudah cukup untuk berproses. V sejak tahun 2005 sudah mengenal Salafi ketika menjadi mahasiswa Fakultas Perikanan Universitas Brawijaya Malang sedangkan 0 masih aktif sebagai mahasiswa Fakultas Pertanian Universitas Brawijaya Cabang Kediri yang mengenal Salafi sejak awal semester III (tahun 2016).

\section{Kesimpulan}

Perempuan Salafi tidak "steril" dari pengaruh industri fesyen jilbab yang cenderung stylish.
Tarikan-tarikan fesyen menjadikan jilbab syar'i kelompok Salafi kemudian bergeser dari pakemnya. Jilbab syar'i yang telah dibuat lebih indah memunculkan aspek yang melampaui makna syar'i. Kondisi ini memberikan pemahaman bahwa kelompok Salafi yang mengklaim dirinya puritan tidak bisa membendung terpaan fesyen jilbab syar'i yang menyasar jamaah perempuannya.

Jilbab syar'i yang mengalami estetisasi menjadi ruang representasi bagi informan $\mathrm{V}$ dan $\mathrm{O}$ untuk mengekspresikan dirinya. Keberadaan industri fesyen jilbab syar'i menjadi solusi pemenuhan hasrat kedua informan karena sebelumnya mereka tidak pernah merasakannya. Mereka mengonstruksi identitas kekinian yang menjadi bagian kesenangan diri (self pleasure) karena bisa merasakan kepuasan batin. Hal ini menunjukkan kondisi pembentukan identitas perempuan Salafi yang tidak statis, tapi terus berubah mengikuti perkembangan zaman meskipun ada wacana dominan dalam praktik berjilbab syar'i.

Usaha-usaha untuk menerobos pagar syar'i dilakukan dengan cara menggunakan jilbab syar'i yang diestetisasi dan tetap menyelaraskan aturan kelompok Salafi. Hal ini dilakukan agar tidak kebablasan dalam mengenakan fesyen jilbab syar'i dalam kehidupan sehari-hari yang penuh dominasi dari berbagai aktor, seperti ustadz, dosen, perempuan Salafi senior, ibu, ibu mertua, dan kakak laki-laki. Dengan demikian, mereka tetap menyesuaikan konteks ruang dan waktu yang menyertainya.

Informasi perkembangan fesyen jilbab syar'i didapatkan dari internet. $\mathrm{V}$ dan $\mathrm{O}$ bisa menge- 
tahui referensi jilbab syar'i yang terbaru melalui media sosial yang dimilikinya. Dalam hal ini, teksteks berjilbab syar'i yang diperoleh dari lingkungan Ponpes Imam Muslim Kediri, tempat kedua informan menimba ilmu, tidak menjadi kendali utama dalam menentukan pilihan jilbab syar'i yang dikehendaki.]

\section{Daftar Pustaka}

Abdullah, Irwan. 2016. Kontruksi dan Reproduksi Kebudayaan. Yogyakarta: Pustaka Pelajar.

al-Albani, Muhammad Nashirudin. 2014. Kriteria Busana Muslimah. Jakarta: Pustaka Imam Asy-Syafii.

Amrullah, Eva. F. 2013. "Perkembangan Styles dan Desain Busana Muslim."

Barnard, M. 2011. Fashion sebagai Komunikasi. Yogyakarta: Jalasutra.

Baswedan, Sufyan bin Fuad. 2013. Samudera Hikmah di Balik Jilbab Mslimah. Jakarta: Pustaka al-Inabah.

Chozin, Muhammad Ali. 2013. "Strategi Dakwah Salafi di Indonesia." Jurnal Dakwah 14(1):1-25.

Daymon, Christine and Immy Holloway. 2008. Metode-metode Riset Kualitatif dalam Public Relations \& Marketing Communications. Yogyakarta: Bentang.

Entwistle, J. 2001. "The Dressed Body." Pp. 33-58 in Body Dressing, ed. J. Entwistle dan E. Wilson. New York: Oxford International Publishers Ltd.

Featherstone, Mike. 2008. Posmodernisme dan Budaya Konsumen. Yogyakarta: Pustaka Pelajar.
Fiske, John. 2000. "Shopping for Pleasure: Malls, Power, and Resistance." dalam The Consumer Society Reader, ed. J. B. Schor dan D. B. Holt. New York: The New Press.

Ghofur, A. 2012. "Perubahan Mode Jilbab dan Pengaruhnya terhadap Perspektif Pemakaian Jilbab: Kasus Pada Mahasiswi Jurusan Sosiologi dan Antropologi Unnes."

Hall, Stuart. 1997. Representation: Cultural Represenattion and Signifying Practices. London: SAGE Publication.

Hasan, Noorhaidi. 2008. Laskar Jihad. Jakarta: LP3ES.

Jones, Carla. 2007. "Fashion and Faith in Urban Indonesia." Fashion Theory - Journal of Dress Body and Culture 11(2-3):211-32.

Lukman, Abu Abdillah Syahrul Fatwa Bin. 2015. Wanita dan Mode: Panduan Berhias Wanita Muslimah Sesuai Alquran dan Assunnah. Gresik: Yayasan Al Furqon Al Islami.

Maryamah, Siti. 2016. "Gamis Syari Kini Tak Lebih dari Sekedar Fashion."

Putra, Heddy Shri Ahimsa. 2009. "Paradigma Ilmu Sosial Budaya: Sebuah Pandangan." Sekolah Pascasarjana Universitas Pendidikan Indonesia.

Sokowati, Muria Endah. 2015. Rekigion, Media, and Marketing in a Complex Society, Agama, Media dan Pemasaran Dalam Masyarakat Majemuk. Yogyakarta: Buku Litera.

Strinati, D. 2016. Popular Culture: Pengantar Menuju Teori Budaya Populer. Yogyakarta: Narasi-Pustaka Promothea.

Utami, E. 2017. "Upaya Indonesia Menjadi Kiblat 'Modest Fashion' pada 2020.” 